\title{
Vetoomus Tiede ja edistyksen valtionavun puolesta
}

Opetusministeri Kalevi Kivistölle luovutettiin 28. 3. 1979 seuraava vetoomus:

Tiede ja edistys -lehti on ilmestynyt kaksi vuotta. Syksyn 1976 näytenumeron jälkeen on ilmestynyt kaksi nelinumeroista vuosikertaa. Tiede ja edistys on maamme ainoa kaikki alat kattava tieteellinen aikakauslehti. Suomen Akatemian yhteiskuntatieteellinen toimikunta totesi 21. 12. 1977 käsitellessään lehden avustusanomusta vuodeksi 1978: "' 'Tiede ja edistys' -lehti sisältää kolmentyyppisiä artikkeleita: yleistieteellisiä, erityistieteellisiä (monilta aloilta) ja myös tiedepoliittisia. Kahdella ensimmäisellä ryhmällä on niin korostettu asema, että lehti tältä kannalta voidaan periaatteessa laskea akatemian tuen piiriin kuuluviin lehtiin."

Lehden kahden ensimmäisen vuosikerran numeroihin sisältyy nimikkeitä luonnontieteellisten teorioiden esittelystä filosofiaan ja ajankohtaisten keskusteluteemojen tieteellisestä syventämisestä yhteiskuntatieteisiin. Sisältönsä perusteella lehti ansaitsee määreen tieteellinen. Lehti edustaa maamme ainoana tieteellisenä lehtenä marxilaista tutkimusperinnettä, esittelee sen tuloksia sekä kehittää keskustelua marxilaisten ja muiden tutkijoiden kesken. Lehti on antanut maamme tieteelliselle keskustelulle runsaasti virikkeitä.

Tiede ja edistys on jäänyt toistaiseksi täysin vaille valtion taloudellista tukea. Tieteellisen aikakauslehden julkaiseminen ilman yhteiskunnan tukea on erittäin vaikeata. Vetoamme siksi opetusministeriöön, että Tiede ja edistys -lehdelle myönnettäisiin vuonna 1979 valtionapua sen julkaisemisen turvaamiseksi riittävä määrä.

VTT Risto Alapuro

OTT Eero Backman

Apul.prof. Raimo Blom

Dos. Kettil Bruun

OTL Lars D. Eriksson

Prof. Antti Eskola

Prof. Jeddi Hasan

Prof. Pertti Hemanus

Prof. Ilkka Heiskanen

Prof. Jukka Hyrkkänen

Prof. Yrjö-Paavo Häyrynen

Lains.neuvos Risto Jaakkola

VTL Raija Julkunen

Apul.prof. Antero Jyränki

Prof. Allen Järvenpää

Dos. Timo Järvilehto

Prof. Pertti Karkama

Apul.prof. Osmo Koskelainen
Pääjohtaja, dos. Pekka Kuusi

Prof. Kari Lagerspetz

Prof. Kirsti Lagerspetz

Prof. Yrjö Littunen

Prof. Juha Manninen

Dos. Klaus Mäkelä

Prof. Jaakko Nousiainen

Prof. Kaarle Nordenstreng

Apul.prof. Hannu Nurmi

Ylijohtaja, dos. OE Niitamo

VTL Arto Noro

VTL Juha Partanen

VTL Jukka Pekkarinen

Apul.prof. Veikko Pietilä

Prof. Seppo Randell

Apul.prof. Jeja-Pekka Roos

Apul.prof. Timo Toivonen

Dos. Ilkka Tuominen 
Prof. Olli Vehviläinen

Dos. Kari Vepsäläinen

Dos. Matti Viikari
Dos. Osmi Vilhu

Prof. Raimo Väyrynen

Ministeri Kivistö ja muut Opetusministeriön edustajat totesivat vetoomuksen luovutustilaisuudessa mielipiteenään, että Tiede ja edistys kuuluisi periaatteessa Suomen Akatemian tiedelehtituen piiriin.

\section{Tässä numerossa}

Lääketieteen etiikasta Suomessa käyty keskustelu on rajoittunut usein yksilöeettisiin ongelmiin tai harvinaisiin kliinis-eettisiin erityistapaukseen. Lääketieteen tutkimuksen ja käytännön etiikan yhteiskunnallisia ehtoja ei olla riittävästi tutkittu. Kuitenkin yhteiskunnalliset suhteet vaikuttavat monin tavoin koko lääketieteen kenttää: yksityispraktiikkaan, yksityiseen työterveydenhuoltoon, lääketeollisuuteen jne. Seppo Aro avaa tästä näkökulmasta lehdessämme keskustelun lääketieteen etiikasta.

Ottar Broxin nimi ei ole varmasti useimmille lehtemme lukijoille tuttu. Brox on norjalainen, pohjoismaisen maaseutusosiologian klassikko, jonka teokset ovat olleet keskeisellä sijalla yliopistojemme tutkintovaatimuksissa. Häneen on usein viitattu uusalkiolaisuudesta käydyssä keskustelussa. Broxin ajatuksia hyödyntää myös viime aikoina meilläkin markkinoitu norjalainen ekomarxisti Hartvig Saetra. Brox edustaa hyvin tyypillista vasemmistopopulistista ajatusmaailmaa. Heikki Sarmaja esittelee ja kritisoi Broxin pääteosta.

Suomalaisessa tieteellisessä keskustelussa ei juuri ole vielä esiintynyt ranskalaisen René Thomin kehittämä matemaattinen teoria, jota kutsutaan katastrofiteoriaksi. Katastrofiteoriaa on pidetty kiintoisimpana matemaattisen ajattelun laajennuksena sen jälkeen kun informaation käsite ja kyberneettiset mallit ilmaantuivat 1940-luvulla. Juha Partanen, Jukka Mäkinen ja Matti Saraste esittelevät kriittisesti tätä teoriaa ja siitä käytyä keskustelua.

Anders Chydeniuksen syntymästä tuli alkuvuodesta kuluneeksi 250 vuotta. Kimmo Sarje ei pyri kirjoituksessaan esittelemään Chydeniuksen ajattelua yleisesti, vaan keskittyy tutkimaan Carl von Linnén vaikutusta Chydeniukseen. Sarjen teesi on, että Chydeniusta ei olla yleensä tarkasteltu kyllin kiinteässä yhteydessä 1700-luvun Ruotsi-Suomen muuhun aatteelliseen elämään ja näin Chydenius on jäänyt omituiseksi yksityisajattelijaksi.

Ranskalainen kulttuurikeskustelu välittyy Suomeen useimmiten vain porvarillisen ja sensationalistisen uutisvälityksen kautta. Tämä koskee niin eurokommunismikeskustelua kuin myös ilmiötä nimeltä "uusi filosofia". Julkaisemme tässä numerossa tunnetun ranskalaisen filosofin Louis Althusserin koulukuntaa edustavan Dominique Lecourtin haastattelun, jossa Lecourt kertoo ennen kaikkea erilaisista tavoista suhtautua "uuden filosofian" synnyttämään ideologiseen tilanteeseen. 